Our Nature (2012) 10: 53-60

\title{
Butterfly diversity and abundance with reference to habitat heterogeneity in and around Neora Valley National Park, West Bengal, India
}

\author{
Utpal Singha Roy ${ }^{1 *}$, Mayukh Mukherjee ${ }^{2}$ and S. K. Mukhopadhyay ${ }^{3}$ \\ ${ }^{1}$ Department of Zoology and PG Department of Conservation Biology, Durgapur Government College, JN \\ Avenue, Durgapur- 713214, West Bengal, India. \\ ${ }^{2}$ Department of Conservation Biology, Durgapur Government College, JN Avenue, Durgapur - 713214, West \\ Bengal, India. \\ ${ }^{3}$ Department of Zoology, Hooghly Mohsin College, Chinsurah - 712101, West Bengal, India. \\ *E-mail:srutpal@gmail.com
}

\begin{abstract}
Butterfly diversity in and around Neora Valley National Park (NVNP), West Bengal, India was studied from three different habitat types that included thick vegetation assemblage with closed canopy cover, edges of forest and areas of human intervention during April May 2010. A total of 30 butterfly species belonging to the families of Hespeririidae (3.33\%), Papilionidae (16.65\%), Pieriidae (13.32\%), Nymphalidae (53.28\%) and Lycaenidae $(13.32 \%)$ were identified in the present investigation. Highest butterfly diversity and abundance was recorded from areas of forest edges (54.83\% of individuals represented by 16 different species), while dense forest (30.64\% of individuals represented by 11 different species) and areas with human habitats (14.52\% of individuals represented by 8 different species) showed lower butterfly diversity and abundance. Accordingly highest Shannon Weiner diversity score of 2.32 was recorded from areas of forest edges. The butterflies that showed high occurrences were Indian Tortoise Shell (Aglais cashmiriensis), Yellow Coster (Acraea issoria) and Himalayan Five Ring (Ypthima sakra). Only 1 butterfly species, Yellow Coster (A. issoria) was found to co-occur in all the three sites. Accelerating human civilizations has lead to destruction of much of the global natural habitats while it has often been found to exert adverse effects on biodiversity. Findings made during this study also indicate negative influence of anthropogenic intervention on overall butterfly diversity from the present location.
\end{abstract}

Key words: Biodiversity hotspot, butterfly, canopy closure, diversity indices, habitat heterogeneity, Neora Valley National Park.

\section{Introduction}

Biologists around the globe are facing particularly great conservation challenges under the mounting threats of anthropogenic disturbances to biodiversity. Moreover, holistic inventory of diversity requires nearly impossible levels of time and effort (Lawton et al., 1998). Insects, representing majority of animal species (ranging anywhere from 5-30 million) are a perfect example of these challenges (Godfray et al., 1999). Consequently insects remain mostly undiscovered and are frequently omitted from conservation assessments (Leather et al., 2008). Butterflies represent an oppor- 
Utpal Singha Roy, Mayukh Mukherjee and S. K. Mukhopadhyay / Our Nature (2012) 10: $53-60$

tunity in this respect, in that many species can typically be sampled and identified in a short time and provide an indication of habitat or conservation value as well (Brown, 1997). Among the 19,238 described global butterfly species (Heppner, 1998) India hosts 1,501 species of butterflies (Gaonkar, 1996).

Neora Valley National Park (NVNP), located in the Eastern Himalayas is a global 'biodiversity hotspot'. The compact virgin forest of NVNP belongs to an Important Bird Area (Islam and Rahmani, 2004). Relationships between habitat and butterfly diversity are well on record from different parts of the Indian subcontinent (Ramesh et al., 2010; Tiple and Khurad, 2009). The present rapid assessment attempts to prepare a checklist of butterflies as well as aims to compare butterfly diversity from closed canopy cover areas of NVNP, its edges and in areas where forests are subjected to various degrees of pressure from human disturbances.

\section{Materials and methods}

Neora Valley was registered as a National Park way back in the year 1992 based on the provisions of the Wildlife (Protection) Act 1972 and covers two biomes, the SinoHimalayan Temperate Forest (Biome - 7) from $1800 \mathrm{~m}$ to $3600 \mathrm{~m}$ of elevation and the Sino-Himalayan Subtropical Forest (Biome - 8) from $1000 \mathrm{~m}$ to $2000 \mathrm{~m}$ of elevation (Islam and Rahmani, 2004). According to Champion and Seth (1968) the phytogeography of NVNP consists of the Subtropical Broadleaf Hill Forest, Montane Wet Temperate Forest and Subtropical Pine Forest and lies in the biogeographic zone 2
(Rodgers et al., 2002). Floral and faunal composition of NVNP typically represents that of Oriental region with high endemism. Human settlements of late around this protected area have altered the biodiversity by means of habitat degradation. This region is a major tourist attraction presently and this in addition with the pressure for livelihood of local people is forcing the conversion of this biodiversity paradise.

Three contrasting forest patches were chosen in the present study depending upon the complexity of habitat structure. Thick vegetation assemblage with closed canopy cover, edges of forest and areas of human intervention in and around NVNP were studied for butterfly diversity and has been referred to as Study Area - $1\left(27^{\circ} 05^{\prime} 49^{\prime \prime} \mathrm{N}\right.$; $88^{\circ} 41^{\prime 2} 9^{\prime \prime} \mathrm{E} ; 1927 \mathrm{~m} \mathrm{msl}$ ), Study Area - 2 $\left(27^{\circ} 06^{\prime} 01^{\prime \prime} \mathrm{N} ; 8^{\circ} 40^{\prime} 33^{\prime \prime} \mathrm{E} ; 1612 \mathrm{~m} \mathrm{msl}\right)$ and Study Area - $3\left(27^{\circ} 05^{\prime} 11^{\prime \prime} \mathrm{N}\right.$; $88^{\circ} 39^{\prime} 41^{\prime \prime} \mathrm{E} ; 2061 \mathrm{~m} \mathrm{msl}$ ) in the present investigation (Fig. 1). NVNP was found to be primarily dominated by species of Quercus, Taxus, Tsuga, Acer, Betula, Castanopsis, Magnolia and Michellia while Bamboo (Arundinaria spp.) was found to be dominant in the understory.

In the present study observations were made during 28.04.10 - 04.05.10 following a fixed daily three transects for each study location of $500 \mathrm{~m}$ length with $5 \mathrm{~m}$ on either side covered in an hour walking at a constant pace between 06:00 hrs and 04:00 hrs. The samplings were continued for seven consecutive days and resulted in a final count of 21 transects form each study location (hence a total of 63 transects were studied). All the butterflies on the line as well as $5 \mathrm{~m}$ on each side were recorded with 


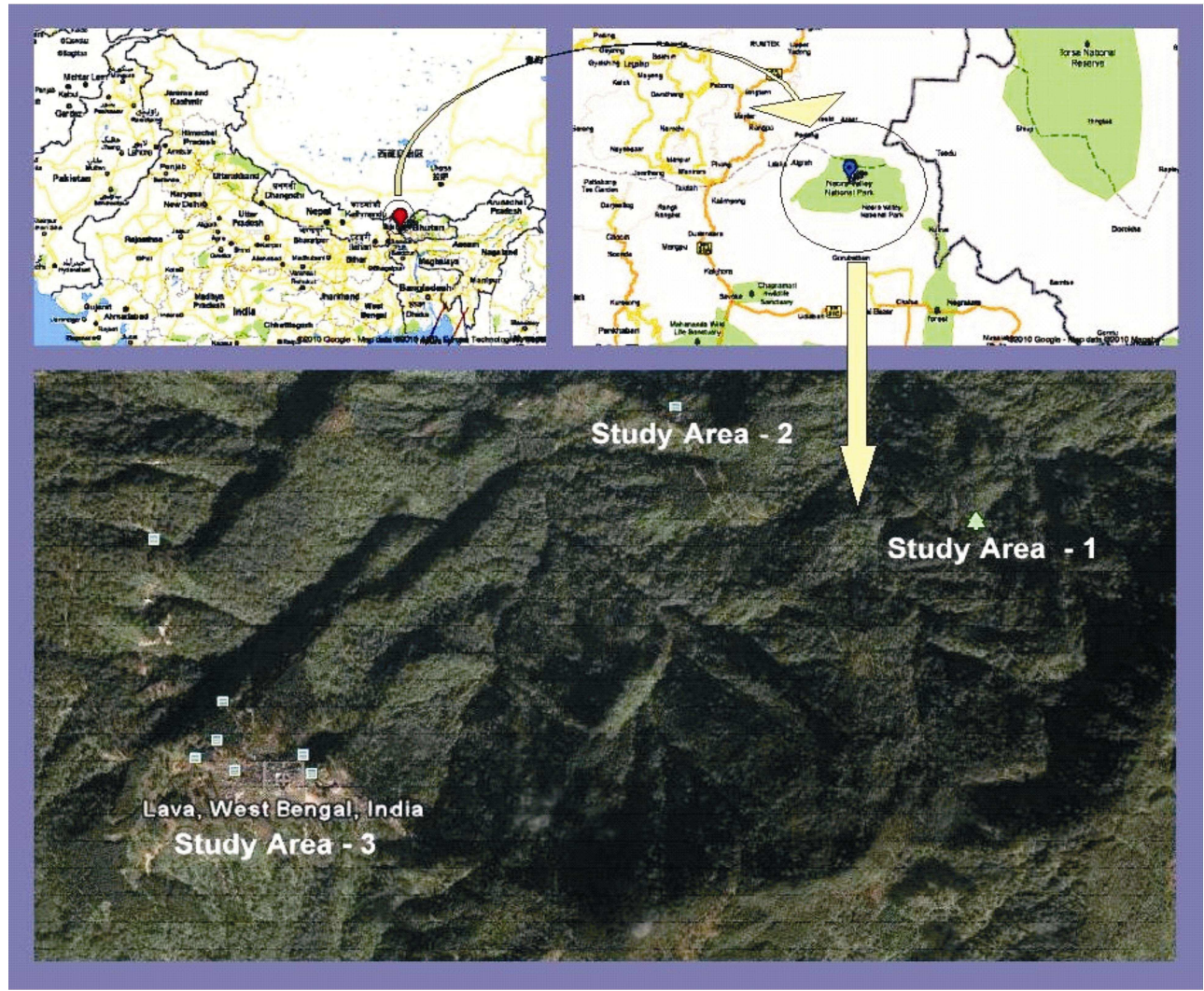

Figure 1. Map of the three study areas (Study Area - 1, Study Area - 2 and Study Area - 3) in and around Neora Valley National Park.

respective time and number of individuals seen. Butterfly species were identified directly in the field or in difficult cases following photography and identification following Haribal (1992) and Kehimkar (2008). No capture or collections were made during the present study.

All the diversity indices were calculated by applying PAST statistical software. Hierarchical cluster analysis was done to construct a dendrogram for commenting on the relation between the studies areas, using SPSS 13.0.

\section{Results}

A total of 30 butterfly species belonging to families of Papilionidae, Pieriidae, Nymphalidae, Lycaenidae and Hespeririidae were recorded during the short period of present study (Tab. 1).

Family wise distribution of all the butterfly species varied widely among all the three study sites with Nymphalidae having the highest representative species followed by Papilionidae (Fig. 2).

Highest butterfly diversity was recorded in Study Area - 2 (total species 
Utpal Singha Roy, Mayukh Mukherjee and S. K. Mukhopadhyay / Our Nature (2012) 10: 53-60

Table 1. Checklist of butterflies along with their status and abundance (average butterfly number $\mathrm{m}^{-2}$ ) for the three Study Areas (SA 1, 2 and 3) in and around Neora Valley National Park. (C = Common, NR = Not Rare and LC $=$ Locally Common).

\begin{tabular}{|c|c|c|c|c|c|}
\hline Common name & Scientific name & Status & $\mathrm{SA}-1$ & $\mathrm{SA}-2$ & $\mathrm{SA}-3$ \\
\hline Small Branded Swift & Pelopidus mathias & $\mathrm{C}$ & 00 & 01 & 00 \\
\hline Common Blue Apollo & Parnassius hardwickii & $\mathrm{C}$ & 00 & 01 & 00 \\
\hline Great Jay & Graphium Eurypylus & NR & 00 & 00 & 01 \\
\hline Blue Mormon & Papilio polymnestor & NR & 00 & 00 & 01 \\
\hline Redbreast & Papilio alcmenor & NR & 00 & 00 & 01 \\
\hline Common Rose & Atrophaneura aristolochiae & $\mathrm{C}$ & 01 & 00 & 00 \\
\hline Common Grass Yellow & Eurema hecabe & $\mathrm{C}$ & 02 & 00 & 04 \\
\hline Yellow Orange Tip & Ixias pyrene & $\mathrm{C}$ & 00 & 10 & 00 \\
\hline Striped Albatross & Appias libythea & $\mathrm{LC}$ & 01 & 00 & 00 \\
\hline Indian Cabbage White & Pieris canidia & $\mathrm{C}$ & 02 & 00 & 00 \\
\hline Powdery Green Sapphire & Heliophorus tamu & NR & 00 & 01 & 00 \\
\hline Pale Grass Blue & Pseudozizeeria maha & $\mathrm{C}$ & 01 & 00 & 00 \\
\hline Dark Judy & Abisara fylla & $\mathrm{C}$ & 01 & 00 & 00 \\
\hline Punchinello & Zemeros flegyas & $\mathrm{C}$ & 02 & 00 & 00 \\
\hline Blue Tiger & Tirumala limniace & $\mathrm{C}$ & 00 & 00 & 01 \\
\hline Double Branded Crow & Euploea sylvester & $\mathrm{LC}$ & 00 & 00 & 8 \\
\hline Long- Branded Blue Crow & Euploea algea & $\mathrm{NC}$ & 00 & 03 & 00 \\
\hline Straight-Banded Tree Brown & Lethe verma & $\mathrm{C}$ & 01 & 00 & 00 \\
\hline Himalayan Fivering & Ypthima sakra & $\mathrm{C}$ & 14 & 02 & 00 \\
\hline Yellow Coster & Acraea issoria & $\mathrm{LC}$ & 05 & 02 & 01 \\
\hline Red Lacewing & Cethosia biblis & $\mathrm{C}$ & 00 & 10 & 00 \\
\hline Green Commodore & Sumalia daraxa & NR & 00 & 10 & 00 \\
\hline Common Lascar & Pantoporia hordonia & $\mathrm{C}$ & 00 & 01 & 00 \\
\hline Clear Sailer & Neptis clinia & $\mathrm{C}$ & 00 & 03 & 00 \\
\hline Black Prince & Rohana parisatis & NR & 00 & 01 & 00 \\
\hline Circe & Hestina nama & NR & 00 & 02 & 00 \\
\hline Indian Red Admiral & Vanessa indica & $\mathrm{C}$ & 00 & 03 & 00 \\
\hline Painted Lady & Vanessa cardui & $\mathrm{C}$ & 00 & 02 & 00 \\
\hline Indian Tortoiseshell & Aglais cashmiriensis & $\mathrm{C}$ & 08 & 16 & 00 \\
\hline Autumn Leaf & Doleschallia bisaltide & NR & 00 & 00 & 01 \\
\hline
\end{tabular}

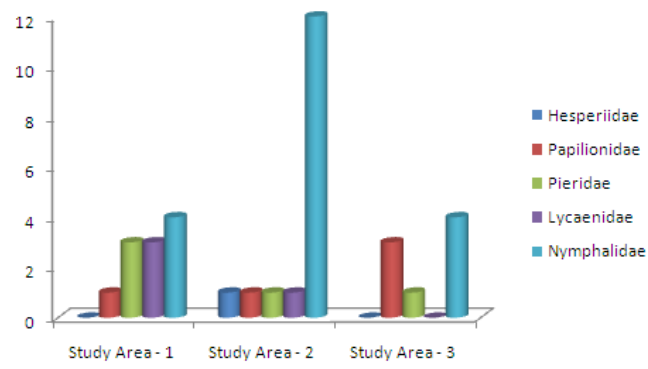

Figure 2. Family-wise distribution of butterfly species from the three study areas (Study Area - 1, Study Area - 2 and Study Area - 3) in and around Neora Valley National Park. 
Utpal Singha Roy, Mayukh Mukherjee and S. K. Mukhopadhyay / Our Nature (2012) 10: 53-60

count of 16) followed by Study Area - 1 (total species count of 11) and Study Area 3 (total species count of 8). Fig. 3 represents the commonality of occurrence among the three study sites. The transition zones between Study Area - 1 and Study Area - 2, Study Area -2 and Study Area -3 and Study Area -1 and Study Area -3 are represented by 3,2 and 1 butterfly species respectively. Only 1 butterfly species Yellow Coster (A. issoria), was found to cooccur in all the three sites.

All the diversity indices studied in the present investigation were always found to be invariably higher at Study Area-2 (Tab. 2).

Dendrogram analysis (Fig. 4) showed that Study Area -1 and Study Area-3 were nearer to each other while most diverse forest edges of Study Area-2 were the farthest.

\section{Discussion}

Since British Raj, thousands of hectares of rich virgin forestlands of Eastern Himalayan region have been cleared off for timber harvesting, or to accommodate tea gardens in the pristine rain-forested and undulating grassland areas. Later, the pressure of growing population and the demand of civilization have further decimated the jungle of these regions. Breathtaking scenic beauty attracts crores of national and international tourists throughout the year that too put a lot of pressure on the ecosystem. Moreover, the consequence of degradation of large forest areas on insect livelihood is poorly understood (Sayer and Whitmore, 1991). Keeping all these in view measurement of species diversity and abundance has become critically important to understanding forest communities and their conservation.

As it is almost impossible to record diversity in a holistic manner recent directives to estimate forest diversity for conservation have concentrated on performing rapid inventories (Anon, 1993; Roberts, 1991), that too utilizing individual taxa (Noss, 1990; Pearson, 1994; Ryti, 1992), or by developing extrapolation techniques to estimate diversity in a variety of habitat types (Colwell and Coddington, 1994; Hammond, 1994; Kiester et al., 1996). Again habitat association of butterflies can be directly related to the availability of larval host plants, vegetation cover of herbs, shrubs and trees for nectaring of butterflies (Thomas, 1995).

Butterfly diversity in the tropics is highly endemic and mostly depends on forest vegetation (Collins and Morris, 1985; Sutton and Collins, 1991). Kitahara and Fujii (1994) have predicted lesser butterfly diversity in regions with high human disturbances. Accordingly Blair and Launer (1997) have recorded fewer butterfly species and reduced overall abundance with increasing urbanization in California. Extinction of species with more restricted distribution and therefore of high conservation values has often been found to be resulted from disturbances (Hamer et al., 1997; Hill et al., 1995).

The present results demonstrate that the relative abundance and diversity of butterfly species was highest in forest edges (Study Area-2) comprising of both habitat generalist and habit specialist predicting that it was the best place for butterfly 
Utpal Singha Roy, Mayukh Mukherjee and S. K. Mukhopadhyay / Our Nature (2012) 10: 53-60

Table 2. Diversity indices for butterfly species from Study Areas (SA 1, 2 and 3) in and around Neora Valley National Park.

\begin{tabular}{llll}
\hline Diversity Indices & SA -1 & SA -2 & SA - 3 \\
\hline Butterfly species & 11 & 16 & 8 \\
Shannon Weiner Diversity & 1.91 & 2.32 & 1.66 \\
Simpson's Dominance Index & 0.79 & 0.87 & 0.73 \\
Pielou's Evenness Index & 0.61 & 0.64 & 0.66 \\
Margalef's Richness Index & 2.75 & 3.56 & 2.42 \\
\hline
\end{tabular}

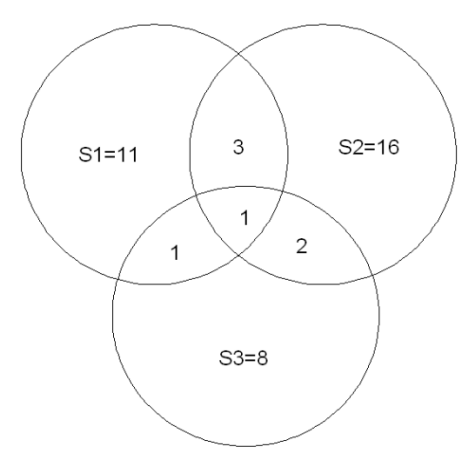

Figure 3. Commonality in co-occurrence of butterfly species from the three study areas (Study Area - 1, Study Area - 2 and Study Area - 3) in and around Neora Valley National Park.
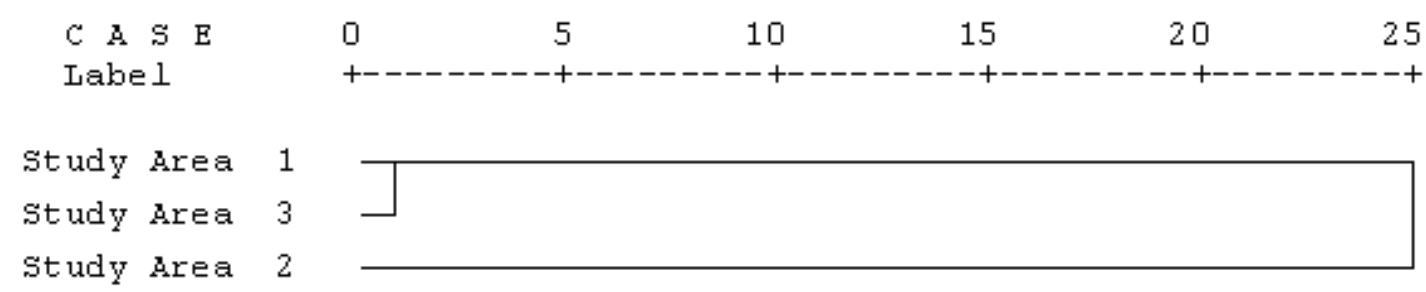

Figure 4. Dendrogram showing the relationship between the three study areas.

aggregation with suitable micro-environmental conditions and easy availability of host plants. Closed canopy cover with dense forest is suitable for only specialized butterfly species and that might have resulted in the present study to record less butterfly diversity from Study Area - 1 .
Present findings also indicated negative influence of anthropogenic intervention on overall butterfly diversity from Study Area -3 .

So far as distribution pattern of butterfly species from the present location is concerned, only one species was found to be 
Utpal Singha Roy, Mayukh Mukherjee and S. K. Mukhopadhyay / Our Nature (2012) 10: 53-60

co-occurring in all the three study sites. This habitat specific distribution of butterflies was reflected in the study of diversity indices where all the indices were always found to be invariably higher in areas of forest edges. Butterfly diversity and abundance in canopy closure were higher than in areas with human interventions but diversity indices score of both the study areas were comparable. This was also reflected in the dendrogram where the most diverse forest edges (Study Area - 2) was found to be separately located from the cluster of Study Area - 1 and Study Area 3. This findings might be attributed to the fact that although both Shannon measures $\left(\mathrm{H}^{\prime}\right)$ and Simpson's index $\left(\mathrm{D}_{\text {SIMP }}\right)$ consider the proportional abundance of species, $\mathrm{H}^{\prime}$ is more sensitive to rare species, whereas $\mathrm{D}_{\text {SIMP }}$ puts emphasis on the common species.

It may be noted that only a few selected patches of forests were studied and that too for shorter time span, a more intensive study would surely result in identifying many more species. Detailed studies could be made to improve the list of butterfly species and to ascertain their characteristic distribution in different forest patches from the present location. The impact of anthropogenic alteration of the habitats in and around Neora Valley National Park also needs intensive studies.

\section{Acknowledgements}

The authors are thankful to the Director of Public Instruction, Government of West Bengal and Divisional Forest Manager, Kalimpong, West Bengal for their kind help and cooperation.

\section{References}

Anon. 1993. Rapid biodiversity assessment. Proceedings of the Biodiversity Assessment Workshop. Macquarie University, Sydney.

Blair, R.B. and A.E. Launer 1997. Butterfly diversity and human land use: species assemblages along an urban gradient. Biological Conservation 80: 113125.

Brown, K.S. 1997. Diversity, disturbance, and sustainable use of Neotropical forests: insects as indicators for conservation monitoring. Journal of Insect Conservation 1: 25-42.

Champion, H.G. and S.K. Seth 1968. A Revised Survey of the Forest Types of India. Government of India, New Delhi.

Collins, N.M. and M.G. Morris 1985. Threatened Swallowtail Butterflies of the World. IUCN, Gland, Switzerland.

Colwell, R.K. and J.A. Coddington 1994. Estimating terrestrial biodiversity through extrapolation. Philosophical Transactions of the Royal Society of London B 345: 108-118.

Gaonkar, H. 1996. Butterflies of Western Ghats with notes on those of Sri Lanka. A report of Center of Ecological Sciences, Indian Institute of science, Bangalore, Zoological Museum, Copenhagen and Natural History Museum, London.

Godfray, H.C.J., O.T. Lewis and J. Memmott 1999. Studying insect diversity in the tropics. Philosophical Transactions of the Royal Society of London B 354: 1811-1824.

Hamer, K.C., J.K. Hill, L.A. Lace and A.M. Langhan 1997. Ecological and biogeographical effects of forest disturbance on tropical butterflies of Sumba, Indonesia. Journal of Biogeography 24: 67-75.

Hammond, P.M. 1994. Practical approaches to the estimation of the extent of biodiversity in speciose groups. Philosophical Transactions of the Royal Society of London B 345: 119-136.

Haribal, M. 1992. The buttreflies of Sikkim Himalaya and their natural history. Sikkim Nature Conservation Foundation, Gangtok.

Heppner, J. 1998. Classification of Lepidoptera. Part I Introduction. Holarctic Lepidoptera 5: 148.

Hill, J.K., K.C. Hamer, L.A. Lace and W.M.T. Banham 1995. Effects of selective logging on tropical butterflies on Buru, Indonesia. Journal of Applied Ecology 32: 454-460. 
Utpal Singha Roy, Mayukh Mukherjee and S. K. Mukhopadhyay / Our Nature (2012) 10:

\section{3-60}

Islam, M.Z. and A.R. Rahmani 2004. Important Bird Area in India: Priority sites for conservation. IBCN, Bombay Natural History Society, BirdLife International, U.K.

Kehimkar, I. 2008. The book of Indian butterflies. Bombay Natural History Society, Oxford University Press.

Kiester, A.R., J.M. Scott, B. Csuti, R.F. Noss, B. Butterfield, K. Sahr and D. White 1996. Conservation prioritization using GAP data. Conservation Biology 10: 1332-1324.

Kitahara, M. and K. Fujii 1994. Biodiversity and community structure of temperate butterfly species within a gradient of human disturbance: an analysis based on the concept of generalist vs. specialist strategies. Researches on Population Ecology 36: 187-199.

Lawton, J.H., D.E. Bignell, B. Bolton, G.F. Bloemers, P. Eggleton, P.M. Hammond, M. Hodda, R.D. Holt, T.B. Larsen, N.A. Mawdsley, N.E. Stork, D.S. Srivastava and A.D. Watt 1998. Biodiversity inventories, indicator taxa, and effects of habitat modification in tropical forest. Nature 391: 72-76.

Leather, S.R., Y. Basset and B.A. Hawkins 2008. Insect conservation: finding the way forward. Insect Conservation and Diversity 1: 67-69.

Noss, R.F. 1990. Indicators for monitoring biodiversity: a hierarchical approach. Conservation Biology 4: 355-364.

Pearson, D.L. 1994. Selecting indicator taxa for the quantitative assessment of biodiversity. Philosophical Transactions of the Royal Society of London B 345: 75-79.
Ramesh, T., K. Jahir Hussain, M. Selvanayagam, K.K. Satpathy and M.V.R. Prasad 2010. Patterns of diversity, abundance and habitat associations of butterfly communities in heterogeneous landscapes of the department of atomic energy (DAE) campus at Kalpakkam, South India. International Journal of Biodiversity and Conservation 2(4): 75-85.

Roberts, L. 1991. Ranking the rain forests. Science 251: 1559-1560.

Rodgers, W.A., H.S. Panwar and V.B. Mathur 2002. Wildlife Protected Area Network in India: A Review (Executive summary). Wildlife Institute of India. Dehradun.

Ryti, R.T. 1992. Effect of the focal taxon on the selection of nature reserves. Ecological Applications 2: 404-410.

Sayer, J.A. and T.C. Whitmore 1991. Tropical moist forests: destruction and species extinction. Biological Conservation 55: 199-213.

Sutton, S.L. and N.M. Collins 1991. Insects and tropical forest conservation. In The Conservation of Insects and Their Habitats (Eds. N.M. Collins, and J.A. Thomas). Academic Press, London, UK. pp. $405-424$.

Thomas, J.A. 1995. The ecology and conservation of Maculinea arion and other European species of large blue butterfly. In Ecology and Conservation of Butterflies (Ed. A.S. Pullin). Chapman and Hall, London. pp: 180-210.

Tiple, A.D. and A.M. Khurad 2009. Butterfly Species Diversity, Habitats and Seasonal Distribution in and Around Nagpur City, Central India. World Journal of Zoology 4(3): 153-162. 